\title{
Foliar Application of Zn Agrichemicals Affects the Bioavailability of Arsenic, Cadmium and Micronutrients to Rice (Oryza sativa L.) in Flooded Paddy Soil
}

\author{
Hamidreza Sharifan (D) and Xingmao Ma * (D) \\ Department of Civil and Environmental Engineering, Texas A\&M University, College Station, TX 77843, USA; \\ hsharifan@tamu.edu \\ * Correspondence: xma@civil.tamu.edu; Tel.: +979-862-1772
}

check for updates

Citation: Sharifan, H.; Ma, X. Foliar Application of $\mathrm{Zn}$ Agrichemicals Affects the Bioavailability of Arsenic, Cadmium and Micronutrients to Rice (Oryza sativa L.) in Flooded Paddy Soil. Agriculture 2021, 11, 505. https://doi.org/10.3390/ agriculture11060505

Academic Editor:

Vasileios Antoniadis

Received: 6 May 2021

Accepted: 28 May 2021

Published: 30 May 2021

Publisher's Note: MDPI stays neutral with regard to jurisdictional claims in published maps and institutional affiliations.

Copyright: (c) 2021 by the authors. Licensee MDPI, Basel, Switzerland. This article is an open access article distributed under the terms and conditions of the Creative Commons Attribution (CC BY) license (https:// creativecommons.org/licenses/by/ $4.0 /)$.

\begin{abstract}
Zinc (Zn) is a key micronutrient affecting bio-functions of crops. Impacts of foliar application of three forms of $\mathrm{Zn}$-containing agrichemicals on the physiology of rice seedlings and their uptake of heavy metal(loid)s and micronutrients from fully flooded paddy soils were investigated in a greenhouse study. Rice seedlings 45 days after germination were randomly exposed to an equivalent amount of $100 \mathrm{mg} \mathrm{L}^{-1}$ of zinc oxide nanoparticles (ZnONPs), zinc oxide bulk particles (ZnOBPs), and zinc salts $\left(\mathrm{Zn}^{2+}\right)$ through foliar exposure. At termination, rice seedlings were divided into roots and shoots and the concerned metal contents in plant tissues were determined with an inductively coupled plasma mass spectrometry (ICP-MS). Our results demonstrated that all Zn agrichemicals displayed a similar effect on plant growth, but ZnONPs led to the greatest root exudate excretion and greatest inhibition in arsenic (As) uptake. Foliar application of ZnONPs resulted in 28\% less As in rice shoots while $\mathrm{Zn}^{2+}$ only caused a $15 \%$ decrease in As accumulation in the same tissues. ZnOBPs had minimal impact on As concentration in rice shoots. ZnONPs also promoted iron (Fe) and copper $(\mathrm{Cu})$ uptake in rice shoots, both of which are essential micronutrients for humans. The results suggest that foliar application of ZnONPs resulted in more favorable outcomes for plant growth and food safety than other two types of Zn. Overall, our results showed that application of nanoagrichemicals have important food safety and nutrition implications in addition to their agronomical roles and ZnONPs could be potentially used to alleviate As uptake and fortify $\mathrm{Zn}$ and other essential micronutrients in rice grains.
\end{abstract}

Keywords: Zinc oxide nanoparticles; rice; foliar application; arsenic; cadmium; micronutrients

\section{Introduction}

The projected global population growth to 9.7 billion by 2050 requires an increase in agricultural production by at least $50 \%$ to achieve sustainable food security [1]. Rice is a staple food for over half of the world's population. Therefore, enhancing rice productivity and the nutritional value of rice grains can be an effective strategy to meet the food and nutritional needs of the world's population. Applications of nano-enabled agrichemicals as soil amendments have generated promising results in improving nutrient utilization efficiency and plant growth $[2,3]$. Among them, zinc oxide nanoparticles (ZnONPs) have been investigated as a more efficient nanofertilizer than bulk $\mathrm{ZnO}$ particles (ZnOBPs) or Zn salts [4,5]. Currently, zinc deficiency is a widespread health risk affecting a large population in developing countries [6,7]. Biofortification of rice grain with $\mathrm{Zn}$ through $\mathrm{Zn}$ fertilization is an economical option because rice is a staple food in most countries suffering from $\mathrm{Zn}$ deficiency [8]. ZnONPs can also function as antimicrobial agents at higher concentrations [9]. This dual functionality of ZnONPs makes them appealing candidates for broad applications in agriculture. However, the introduction of nanoparticles or other agrichemicals as soil amendments can be costly due to their low utilization rate [7,10]. Direct applications of nanoparticles as soil amendments can also have unexpected consequences 
because their close interactions with coexisting environmental chemicals can affect the availability of heavy metals and micronutrients in soil [11]. The observation is consistent with studies with other types of soil amendments that were found to alter the plant uptake and accumulation of coexisting toxic heavy metals $[12,13]$. Contamination of agricultural soils with various coexisting heavy metals and metalloids is a rising concern that has been frequently reported [14-16]. Arsenic is particularly concerning due to its carcinogenicity and widespread presence in rice paddies [17]. Intriguingly, ZnONPs applied to paddy soil as a soil amendment were shown to lower arsenic (As) concentration in rice shoot tissues in a lab scale study [18]. In a hydroponic study, ZnONPs were shown to increase the iron concentration in lettuce (Lactuca sativa L.) shoots by 80\% [19], indicating that ZnONPs applied as a soil amendment may also modify plant nutrient uptake.

However, in almost all previous studies that investigated the impact of nanoparticles on plant uptake and accumulation of coexisting environmental pollutants or plant nutrients, nanoparticles were applied through the root exposure [20-22]. While it is common that nanoagrichemicals are applied as soil amendments [23], this approach can be costly due to their low utilization rate. Recently, foliar application of agrichemicals has become more popular due to its lower demand for chemicals and easier application [24]. Previous studies have shown that different pathways of nanoparticle exposure (e.g., root exposure vs. foliar exposure) can lead to different phytotoxicity and accumulation of nanoparticles in plant tissues because of the distinctive physiological and anatomical differences of root and shoot tissues $[25,26]$. In general, foliar exposure appears to have less negative impact on plant growth than root exposure at the same exposure level. For example, ZnONPs introduced through foliar application improved the growth of cucumber and rice by increasing the physiological and metabolic functions of plants, while root exposure of the same concentration of ZnONPs caused toxicity [27,28]. Importantly, some nanoparticles introduced to plants through the foliar application will not directly contact with environmental chemicals and plant nutrients in soil, therefore, their impact on the availability of these chemicals and plant nutrients could be markedly different from those introduced through root exposure. However, few studies have investigated the effects of engineered nanoparticles on the plant uptake and accumulation of environmental chemicals and plant nutrients after they are introduced to plants through the foliar application. This knowledge gap in nanoparticles uptake through the rice leaf surface and their in planta behavior constrict the rational design for efficient foliar applications of ZnONPs.

Also, ZnONPs are highly soluble and it remains unsettled whether any observed effects by $\mathrm{ZnONPs}$ are due to the dissolved $\mathrm{Zn}$ ions. However, elucidating which form of $\mathrm{Zn}$ is beneficial or detrimental to rice performance in contaminated paddy soils is critical [24]. For example, Zhang et al. in 2018 found that foliar application of ZnONPs led to greater $\mathrm{Zn}$ contents in rice grains than an equivalent amount of $\mathrm{Zn}$ salt [29]. The distribution of $\mathrm{Zn}$ in plant tissues was also slightly different. Such differences could affect rice nutritional values and other minerals in rice grains. The objectives of this study were to (1): investigate the impact of foliar application of ZnONPs on the physiological health of rice; (2) determine how foliar application of ZnONPs affect plant uptake and accumulation of As and cadmium (Cd); and (3) evaluate the impact of foliarly applied ZnONPs on plant micronutrients uptake. Equivalent amounts of $\mathrm{ZnOBPs}$ and $\mathrm{Zn}$ salts were introduced to plants in parallel experiments to generate more insight into the potentially varying impacts of different forms of $\mathrm{Zn}$ agrichemicals.

\section{Materials and Methods}

Negatively charged $\mathrm{ZnONPs}$ ( $20 \%$ by weight, $10-30 \mathrm{~nm}$ ) were purchased from the U.S. Research Nanomaterials, Inc. (Houston, TX, USA). High purity As(V) $\left(\mathrm{Na}_{2} \mathrm{HAsO}_{4} \cdot 7 \mathrm{H}_{2} \mathrm{O}>98 \%\right.$ ) and zinc sulfate heptahydrate $\left(\mathrm{ZnSO}_{4} \cdot 7 \mathrm{H}_{2} \mathrm{O}>99 \%\right)$ were obtained from Sigma Aldrich (St. Louis, MO, USA) and Acros Organics (Geel, Belgium), respectively. Cadmium sulfate $\left(\mathrm{CdSO}_{4}\right)$ was purchased from Fisher Scientific, Inc. (Pittsburgh, PA, USA). Standard solutions of $\mathrm{As}, \mathrm{Zn}$, iron $(\mathrm{Fe})$, and copper $(\mathrm{Cu})(10,000 \mathrm{ppm}$ in 3\% nitric acid) for inductively 
coupled plasma mass spectrometry (ICP-MS) were obtained from RICCA Chemical Co. (Arlington, TX, USA).

\subsection{Characterization of Zinc Oxide Nanoparticles ( $\mathrm{ZnONPs}$ )}

The size and shape of the ZnONPs were fully characterized in our previous study using a Tecnai G2 F20 transmission electron microscope (TEM) [19]. These nanoparticles are primarily spherical, with some triangular and irregular-shaped ZnONPs observed at low percentage. The mean diameter of the primary nanoparticles was around $68.1 \mathrm{~nm}$, ranging from 15 to $137 \mathrm{~nm}$. ZnONPs underwent substantial aggregation in solution and the hydrodynamic diameter increased to $621.08 \pm 7.63 \mathrm{~nm}$ in $100 \mathrm{mg} \mathrm{L}^{-1}$ deionized water as measured by dynamic light scattering (DLS) (Delsa Nano C, Beckman Coulter Inc., Miami, FL, USA). The zeta potential was about $-28.80 \pm 2.04 \mathrm{mV}$.

\subsection{Soil Preparation}

Raw soil was randomly collected from six points of a rice paddy at Beaumont, TX. Coarse organic materials and other large pieces of debris were handpicked first. The cleaned soil was then air-dried for six days at $35^{\circ} \mathrm{C}$. The dried soil was sieved through a $2 \mathrm{~mm}$ sieve following a previous study [30]. The essential physicochemical characteristics of the soil can be found in the same study. The soil was classified as a league clay soil $(65.2 \%$ clay, $4.3 \%$ sand, $30.5 \%$ silt, and $~ 1.76 \%$ of organic matter) according to the U.S. Department of Agriculture (USDA) guideline [30]. The $\mathrm{pH}$ of the soil was around 5.5 measured in a 1:2.5 (v/v) soil to water suspension.

The background concentrations of $\mathrm{As}, \mathrm{Cd}$, and $\mathrm{Zn}$ in the soil were quantified with an ICP-MS (Perkin Elmer mod. DRCII, Waltham, MA, USA) after acid digestion. Briefly, three replicates of the soil samples ( $100 \mathrm{~g}$ ) were randomly selected and oven-dried for $72 \mathrm{~h}$ at $85^{\circ} \mathrm{C}$. One gram of soil subsample was acid digested $\left(4 \mathrm{~mL} \mathrm{HNO}_{3}\right.$ and $2 \mathrm{~mL} \mathrm{H}_{2} \mathrm{O}_{2}$ ) in a $50 \mathrm{~mL}$ tube using DigiPREP MS hot block digester (SCP science, Quebec, Canada) at $95^{\circ} \mathrm{C}$ for $8 \mathrm{~h}$. After being cooled to room temperature, the digested solutions were centrifuged (6000 g) for $10 \mathrm{~min}$ and filtered through $0.45 \mu \mathrm{m}$ membrane filters. The target elements in the supernatant were then analyzed by ICP-MS. The background concentrations of As, $\mathrm{Cd}$, and $\mathrm{Zn}$ were $1.76,0.13$, and $17.4 \mathrm{mg} \mathrm{Kg}^{-1}$, respectively.

\subsection{Experimental Setup}

After the preparation and characterization of the soil, a fresh solution of As and $\mathrm{Cd}$ salts was added to the soil to a level of $5 \mathrm{mg} \mathrm{kg}^{-1}$ As and $1 \mathrm{mg} \mathrm{kg}^{-1} \mathrm{Cd}$ to mimic the average As and $\mathrm{Cd}$ concentrations in agricultural soils in the U.S. More details on the preparation of the soil were described in our earlier publication [18]. We used the same concentration of As and $\mathrm{Cd}$ as in our previous study so that comparisons could be made between the two different exposure pathways of ZnONPs with regard to their impact on the fate and accumulation of As and Cd in rice paddies. Approximately $500 \mathrm{~g}$ of contaminated soil was added to each pot $\left(25 \times 8.5 \times 8.5 \mathrm{~cm}^{3}\right)$. Afterward, each pot was soaked with $2 \mathrm{~cm}$ standing tap water above the soil surface for $48 \mathrm{~h}$ to condition the soil for the rice seed germination. The seeds (Oryza sativa L.) were provided by the Texas A\&M AgriLife Research Center at Beaumont. The seed's surface was sterilized using $30 \% \mathrm{H}_{2} \mathrm{O}_{2}$ for about $15 \mathrm{~min}$ and carefully rinsed with deionized water [31]. The sterilized seeds were then gently placed about $1 \mathrm{~cm}$ below the soil surface for germination. Once the seedlings started growing, tap water was used to replenish the evapotranspiration daily to maintain about $2 \mathrm{~cm}$ of water above the soil surface. During the growth period, pots were randomly rearranged every other day to minimize the impact of light shading. The ambient temperature in the growth chamber was about $28 \sim 30^{\circ} \mathrm{C}$. The seedlings were exposed to fluorescence light with a $6 \mathrm{~h} / 8 \mathrm{~h}$ light/dark cycle for 1.5 months before the foliar treatments.

The plant seedlings were randomly subjected to three targeted foliar applications of $100 \mathrm{mg} \mathrm{L}^{-1} \mathrm{Zn}$ agrichemicals in the form of (i) ZnONPs, (ii) $\mathrm{ZnSO}_{4}$, and (iii) ZnOBPs. A 
control treatment with DI water was also prepared. The $\mathrm{Zn}$ concentration was chosen due to its potential effects on the reduction of heavy metal uptake and higher biomass production in rice [32]. Foliar applications on each treatment were conducted twice with two weeks interval. During the course of treatment, the soil surface was fully covered with a plastic film to avoid the entrance of $\mathrm{Zn}$ into the soil. In each application, a $\frac{1}{2}$ gallon polyethylene hand-held sprayer was used to spray approximately $1 \mathrm{~L}$ of premade solution to each treatment $(n=3)$ before reaching the dripping point [10]. The solutions of $\mathrm{ZnONPs}$ and $\mathrm{ZnOBPs}$ were ultra-sonicated for $30 \mathrm{~min}$ before spraying [32]. After the second application, plants were allowed to grow for another $14 \mathrm{~d}$ before harvest. After the termination, the roots were gently rinsed by DI water, and the rice plants were separated into shoots and roots. The biomass was oven-dried at $75^{\circ} \mathrm{C}$ for $72 \mathrm{~h}$ for further analysis of the total As and $\mathrm{Cd}$ and micronutrients of copper $(\mathrm{Cu}), \mathrm{Fe}$, and $\mathrm{Zn}$.

\subsection{Total As, $\mathrm{Cd}, \mathrm{Cu}, \mathrm{Fe}$, and $\mathrm{Zn}$ Analysis in Plant Tissues}

The total uptake of $\mathrm{As}, \mathrm{Cd}, \mathrm{Cu}, \mathrm{Fe}$, and $\mathrm{Zn}$ in rice tissues was quantified after strong acid digestion in compliance with EPA protocol 3050b. Briefly, $0.65 \mathrm{~g}$ of dried biomass of shoots and $0.3 \mathrm{~g}$ of roots were digested into a $50 \mathrm{~mL}$ digestion tube by $3 \mathrm{~mL} 70 \% \mathrm{H}_{2} \mathrm{NO}_{3}$ $\mathrm{W} / \mathrm{W}$ acid and $2 \mathrm{~mL} \mathrm{H}_{2} \mathrm{O}_{2} 30 \%$ (Certified ACS) for $10 \mathrm{~h}$ at $95^{\circ} \mathrm{C}$ on a DigiPREP MS hot block digester (SCP Science, Clark Graham, Canada) [33,34]. The total concentration of metals in each treatment was measured by ICP-MS (PerkinElmer mod. DRCII, Waltham, MA, USA).

\subsection{Soil Organic Content by Loss-on-Ignition (LOI)}

Five grams of homogenized and sieved $(1 \mathrm{~mm})$ soil sample $(\mathrm{n}=3)$ was weighed into pre-weighed $55 \mathrm{~mm}$ porcelain crucibles. They were then placed in an oven at $110{ }^{\circ} \mathrm{C}$ overnight. After full dehydration, the dried samples were ground and $2 \mathrm{~g}$ of sample was weighed. The oven-dried samples were subsequently placed in a muffle at $550{ }^{\circ} \mathrm{C}$ for $4 \mathrm{~h}$ and cooled down in a desiccator. The combusted samples were weighed again. The weight difference was considered as the total soil organic content as shown by Equation (1) [35].

$$
\operatorname{SOC}\left(\mathrm{g} \mathrm{g}^{-1}\right)=\frac{\mathrm{DW}-\mathrm{CW}}{\mathrm{DW}-\mathrm{W}_{\mathrm{c}}}
$$

where SOC is the soil organic content $\left(\mathrm{g} \mathrm{g}^{-1}\right)$; DW refers to the weight of the sample at $110^{\circ} \mathrm{C}$ plus the weight of crucible $(\mathrm{g}) ; \mathrm{W}_{\mathrm{c}}$ is the weight of the porcelain crucible (g); and $\mathrm{CW}$ is the cumulative weight of the calcinated sample and the crucible (g).

\subsection{Statistical Analysis}

Data acquired on elemental concentrations of $\mathrm{Zn}, \mathrm{Fe}, \mathrm{As}, \mathrm{Cd}$, and $\mathrm{Cu}$ in dry root and shoot tissues as well as associated biomass and soil organic materials were processed using Minitab 18 Statistical Software (Minitab Inc., State College, PA, USA). Through the one-way ANOVA, the mean data differentiation between treatments was analyzed, assisted by Tukey's post hoc test at significance level $5 \%(p<0.05)$.

\section{Results and Discussion}

\subsection{Biomass}

The shoot height, root length, and shoot biomass were all unaffected by the foliar treatment with Zn-containing agrichemicals (Figure 1). However, the dry weight of root biomass was significantly increased by 100,66 , and $64 \%$ after treatment with $\mathrm{Zn}^{2+}, \mathrm{ZnONPs}$, and $\mathrm{ZnOBPs}$, respectively, compared to the control. The differences between the three $\mathrm{Zn}$ agrichemicals were not statistically significant. The greater effect of $\mathrm{Zn}$ salt on rice growth might be due to its easier and faster assimilation into plant tissues that increase the photosynthesis, leading to rice growth. Previous research has shown that sprayed ZnONPs and $\mathrm{ZnOBPs}$ are mostly retained in the waxy layer of plant leaves [10]. 

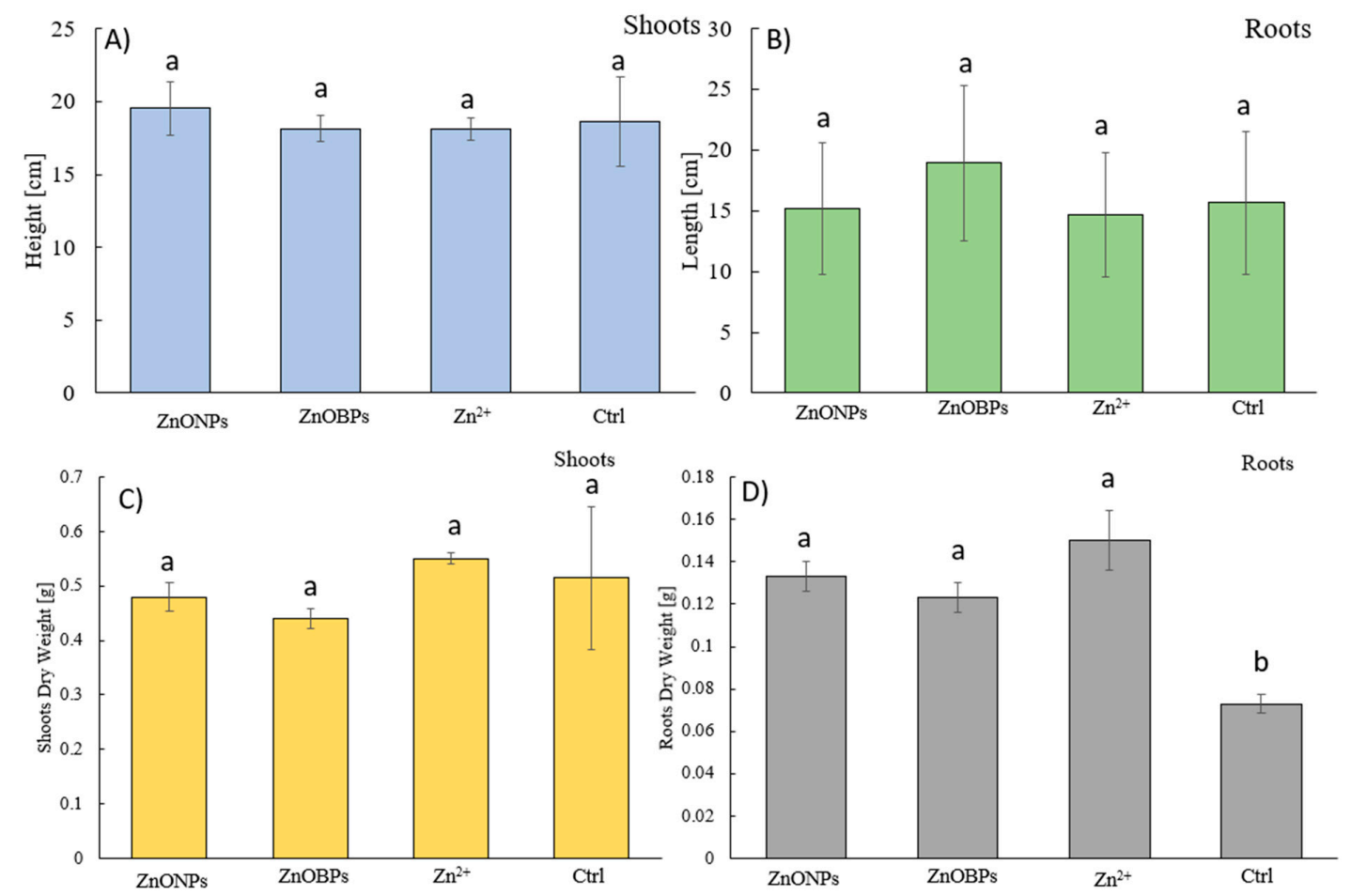

Figure 1. Elongation and dry biomass of Oryza sativa L. tissues treated with $100 \mathrm{mg} \mathrm{L}^{-1}$ of $\mathrm{Zn}$ salt, ZnONPs, and ZnONPs. (A) Shoot height, (B) Root length, (C) Shoot dry biomass, (D) Root dry biomass. Each column represents the mean value of three replicates $(n=3)$ and the error bars indicate standard deviation. Different letters above the bars indicate significant differences $(p \leq 0.05)$.

While the net photosynthesis rate and chlorophyll contents are common indicators of plant physiological health, we instead determined the potential formation of photosynthates and the release of exudates by quantifying the soil organic carbon (SOC) in soil (Figure 2). Consequently, higher SOC could have affected the activity of soil microorganisms and the bioavailability of soil-borne heavy metals and micronutrients. Compared with the control, $\mathrm{ZnONPs}$ significantly increased the SOC while $\mathrm{Zn}^{2+}$ significantly decreased the SOC. These differences were attributed to the differences in the excretion of root exudates and, potentially, the different net photosynthesis rates because root exudates are considered as part of the surplus carbon from photosynthesis [36].

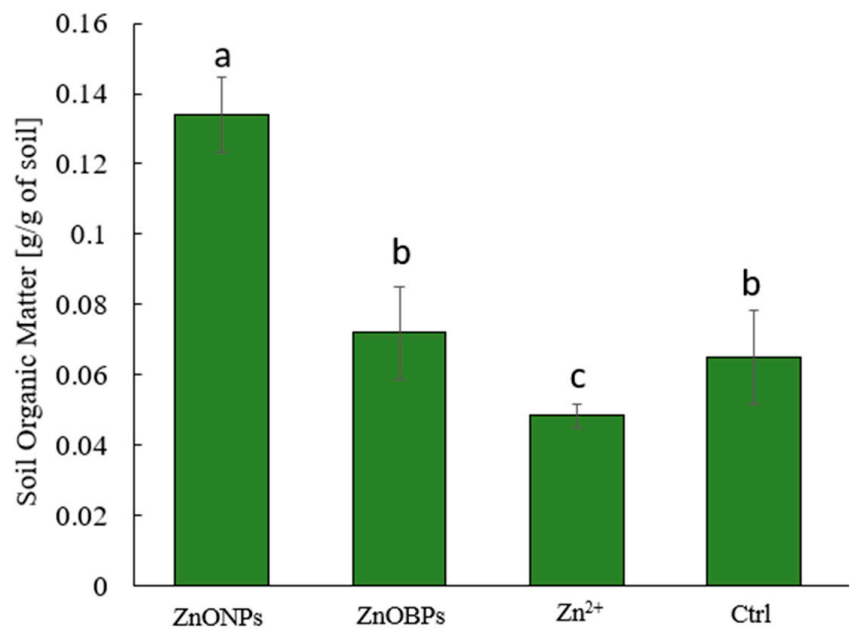

Figure 2. Soil organic content (SOC) in soil pots of each treatment. The letters above each mean data bar indicate that statistical differences were found by the post hoc test $(p<0.05)$. 


\subsection{Arsenic and Cadmium}

The foliar application of different $\mathrm{Zn}$-containing agrichemicals affected the As accumulation in rice tissues differently. ZnONPs and Zn salt significantly lowered the total As accumulation by 28 and $15 \%$ in rice shoots but did not affect the total As in rice roots (Figure 3). In contrast, ZnOBPs did not affect the total As in rice shoots but significantly elevated the total As in rice roots by approximately $40 \%$, compared to the control. None of the $\mathrm{Zn}$ agrichemicals affected $\mathrm{Cd}$ in plant tissues through foliar treatment (Figure 4). However, the $\mathrm{Cd}$ level in roots was slightly higher in cultivars exposed to ZnONPs, compared to the control. We found in our previous study that the application of ZnONPs through root exposure simultaneously reduced $(p<0.05)$ both As and $\mathrm{Cd}$ accumulation in rice shoots, while $\mathrm{Zn}^{2+}$ only decreased As concentration in rice shoots but increased $\mathrm{Cd}$ concentration in rice shoot by $26.8 \%$ [18]. This study agreed with the previous study that $\mathrm{ZnONPs}$ and $\mathrm{Zn}^{2+}$ affected the plant uptake and accumulation of coexisting heavy metals differently. Furthermore, it was found that the particle size of $\mathrm{ZnO}$ particles played a role in the interactions of plants and co-occurring heavy metals. The significantly higher As in both rice roots and shoots following $\mathrm{ZnOBPs}$ treatment was noticed, but the underlying mechanism of ZnOBPs for its stronger effect was unknown. The relatively unaffected $\mathrm{Cd}$ by foliar $\mathrm{Zn}$ spray was understandable because the bioavailability of $\mathrm{Cd}$ to rice is primarily governed by the redox potential in rice paddies. $\mathrm{Cd}$ is more bioavailable in aerobic conditions because $\mathrm{Cd}$ is primarily in the form of $\mathrm{Cd}^{2+}$ in aerobic conditions, but it forms insoluble cadmium sulfide (CdS) in the anaerobic environment. In this study, an anaerobic environment was largely maintained by the standing water above the soil surface. Therefore, $\mathrm{Cd}$ bioavailability to rice seedlings was unaffected by the $\mathrm{Zn}$-containing agrichemicals applied foliarly. The relatively higher $\mathrm{Cd}$ in plant tissues in this study than in our previous study might have resulted because $2 \mathrm{~cm}$ standing water was not adequate to maintain a totally anaerobic environment in the soil. Importantly, this study showed that different pathways of exposure of agrichemicals affected the fate and plant accumulation of various heavy metals differently. Therefore, the food safety implication should be considered when the different pathways of agrichemical applications are considered.
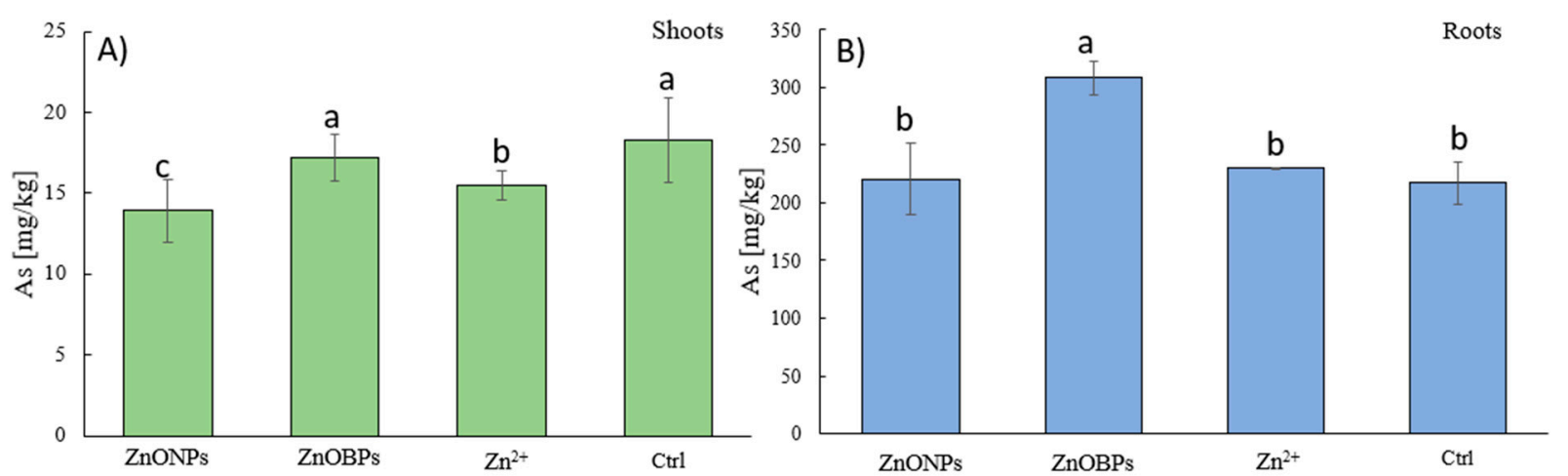

Figure 3. Total arsenic in rice shoots and roots treated with $100 \mathrm{mg} \mathrm{L}^{-1}$ of $\mathrm{Zn}, \mathrm{ZnOBPs}$, and ZnONPs through foliar exposure. (A) The total As in rice shoot and (B) root tissues. Each column represents the average of three replicates $(n=3)$. Error bars represent standard deviation. The letters above each bar show statistical grouping. 


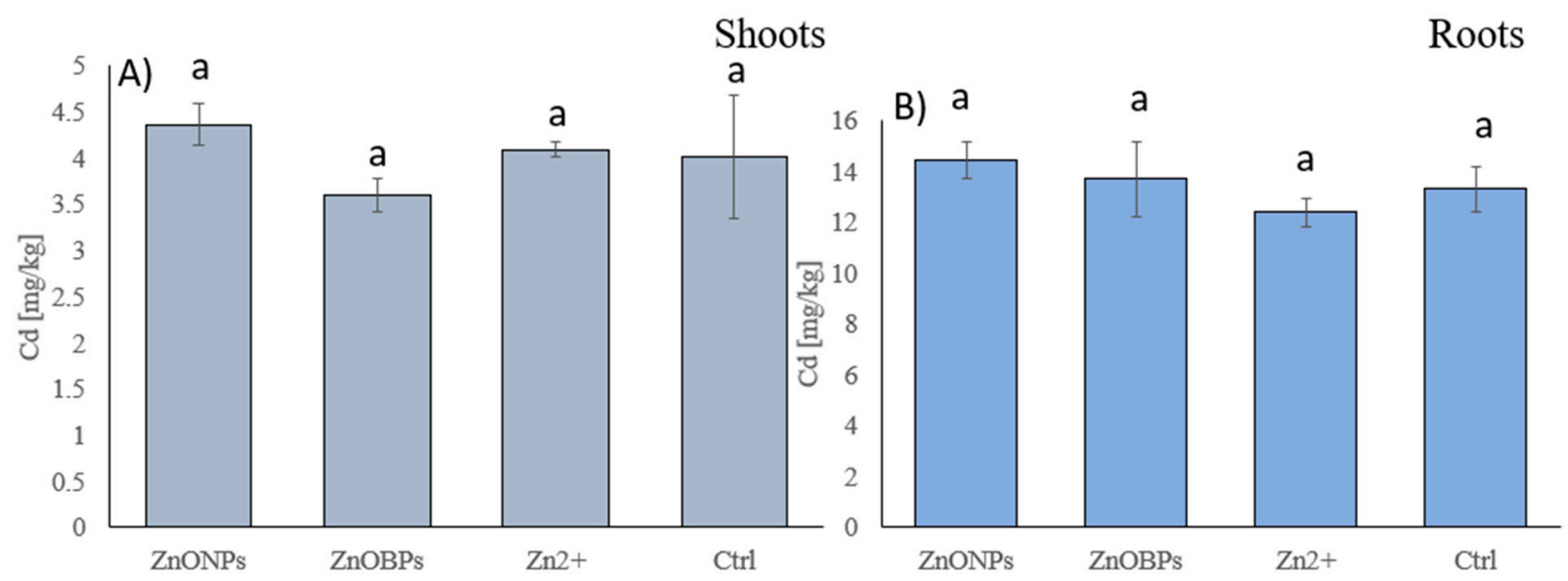

Figure 4. The mean concentration of cadmium content in rice cultivars under foliar application of $100 \mathrm{mg} \mathrm{L}-1$ of $\mathrm{Zn}$, $\mathrm{ZnO}$ bulk, and ZnONPs. (A) The total Cd in shoot tissues and (B) in root tissues. The species were randomly selected for the experiment $(n=3)$. The letters above each column indicate statistical significance. Error bars indicate standard deviation.

\subsection{Micronutrients}

In addition to evaluating the impact of foliar application of $\mathrm{Zn}$ agrichemicals on heavy metals, we also investigated how the foliar exposure to Zn-containing agrichemicals affected plant micronutrient uptake due to their key roles in maintaining the plants' physiological health. Figure 5 shows the plant uptake of Fe in rice roots and shoots from different treatments. $\mathrm{ZnONPs}$ and $\mathrm{Zn}^{2+}$ significantly enriched Fe in rice shoots by 71 and $48 \%$, respectively, compared to the control. Interestingly, the Fe concentration in rice roots was significantly increased by $\mathrm{ZnOBPs}$, while the other two $\mathrm{Zn}$ agrichemicals did not show a significant impact on the Fe concentration in plant roots. In combination with the Fe concentration in rice shoots, it appeared that foliar application of different $\mathrm{Zn}$ agrichemicals affected iron transport from roots to shoots. Similar observations on the effects of ZnONPs on promoting the Fe uptake were reported in an earlier study [37] and the positive correlation between total nitrogen content and the Fe concentration in plant shoots suggests that the promoting effects of ZnONPs on Fe concentration might have led to higher plant photosynthesis efficiency. The observation is consistent with the greater root exudates from ZnONP-exposed rice seedlings, Figure 2.


Figure 5. Total iron uptake from soil in rice plants under different treatments. (A) Fe level in rice shoots and (B) roots from different treatments. Reported data are the mean values of three replicates $(n=3)$. Different letters above each bar indicate significant differences. Error bars indicate standard deviation.

Another micronutrient we examined was $\mathrm{Cu}$, an essential metal cofactor in activating many photosynthesis enzymes and respiratory processes [38]. As shown in Figure 6, the 
accumulation of $\mathrm{Cu}$ in both roots and shoots was significantly promoted by the foliar application of $\mathrm{ZnONPs}$ and $\mathrm{ZnOBPs}$, while $\mathrm{Zn}^{2+}$ showed limited impact on the $\mathrm{Cu}$ content in both rice roots and shoots, compared to the control. ZnONPs increased the $\mathrm{Cu}$ concentration in rice shoots and roots by 5 and $8 \%$, respectively, and ZnOBPs increased the $\mathrm{Cu}$ concentration in rice shoots and roots by 6 and $2 \%$, respectively.

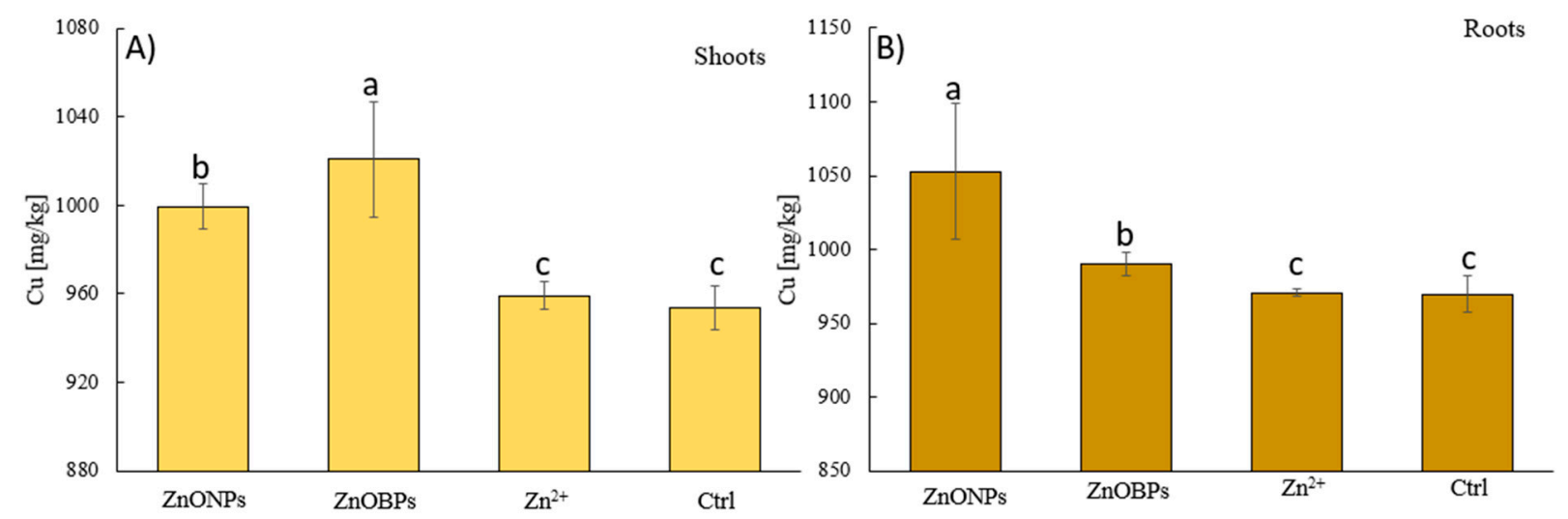

Figure 6. Total concentration of copper in rice. (A) Rice shoots and (B) rice roots from different treatments ( $\mathrm{Zn}, \mathrm{ZnO}$ bulk, $\mathrm{ZnONPs}$, and control). The reported values are the mean of three replicates. Error bars stand for standard deviation and letters above each bar designate grouping of statistical differences $(p \leq 0.05)$.

As expected, the application of Zn-containing agrichemicals to rice cultivars significantly increased the $\mathrm{Zn}$ concentration in plant shoots, and significant differences were observed between different forms of $\mathrm{Zn}$ (Figure 7). ZnONPs, ZnOBPs, and $\mathrm{Zn}^{2+}$ increased the total $\mathrm{Zn}$ content in rice shoots by 16-, 14-, and 12-fold, compared with the control. The $\mathrm{Zn}$ element might be primarily absorbed in the wax layer of leaves, but previous studies have shown that $\mathrm{Zn}^{2+}$ and possibly $\mathrm{ZnONPs}$ can enter into the leaf matrix through stomata [10]. Most likely, the size is a limiting factor in the diffusion of ZnOBPs through the stomata $(19.1$ to $71.5 \mu \mathrm{m})$ [39], which only allows particles of sizes smaller than its opening to pass through. Surprisingly, the foliar application of ZnONPs and ZnOBPs led to substantially higher $\mathrm{Zn}$ in rice roots, while the root tissues from $\mathrm{Zn}^{2+}$-treated seedlings had minimal $\mathrm{Zn}$. This observation may be explained by the incorporation of $\mathrm{Zn}^{2+}$ into the structure of macromolecules through different complexation processes once it enters into the shoot biomass, while $\mathrm{ZnONPs}$ and $\mathrm{ZnOBPs}$ were less available to complex with other molecules and were transported down to the roots from the phloem. Previous studies have shown that cerium oxide nanoparticles $\left(\mathrm{CeO}_{2} \mathrm{NPs}\right)$ were transported down from shoots to roots through the phloem [40].
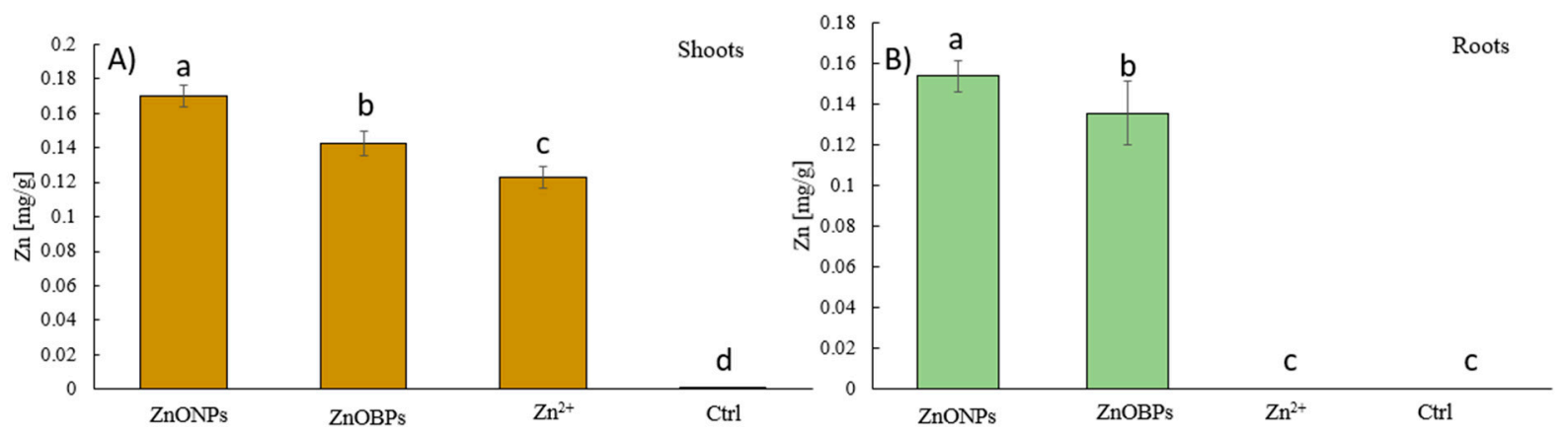

Figure 7. The average concentration of $\mathrm{Zn}$ in (A) rice shoots (B) rice roots exposed to foliar treatments of $\mathrm{Zn}^{2+}, \mathrm{ZnOBPs}$, and ZnONPs. The reported values are the average of three replicates. Error bars designate standard deviation. Letters above the bars indicate the grouping of statistical significance. 
In summary, our study showed that foliar application of $\mathrm{Zn}$-containing agrichemicals will not only affect the physiology of rice seedlings but will also affect the plant uptake of heavy metals and micronutrients from the soil. The effect differed between different forms of $\mathrm{Zn}$ agrichemicals and between different pathways of applications. The concentration of $\mathrm{Zn}$ in rice shoots was highest from the ZnONP treatment, which also resulted in lowest As accumulation in rice shoots. Overall, our results showed that ZnONPs displayed a more favorable outcome than other two forms of $\mathrm{Zn}$ in promoting plant physiology, inhibiting plant accumulation of toxic heavy metal(loid)s, and promoting the uptake of essential micronutrients. Future studies should explore how different concentrations of Zn nanoagrichemicals would affect these various aspects of plant health and food safety differently and how these consequences could be affected by the properties of paddy soil, water management, and nutrient management practices. In an era of exponential population growth, nanotechnology may be one of the most important tools to achieve adequate safe and nutritious food effectively and economically. Detailed studies on the speciation of foliarly applied ZnONPs and other forms of $\mathrm{Zn}$ in plant tissues using more advanced techniques such as X-ray diffraction spectroscopy (XRD) will shed more light on the impact of $\mathrm{ZnONPs}$ on rice growth and the nutritional values of rice grains.

Author Contributions: X.M. conceived and H.S. performed the study. H.S. prepared the first draft and X.M. reviewed and finalized it. Both authors have read and agreed to the published version of the manuscript.

Funding: This research received no external funding.

Institutional Review Board Statement: Not Applicable.

Informed Consent Statement: Not applicable.

Conflicts of Interest: The authors declare no conflict of interest.

\section{References}

1. Kah, M.; Tufenkji, N.; White, J.C. Nano-enabled strategies to enhance crop nutrition and protection. Nat. Nanotechnol. 2019, 14, 532-540. [CrossRef]

2. Zhu, S.; Wang, S.; Yang, X.; Tufail, S.; Chen, C.; Wang, X.; Shang, J. Green sustainable and highly efficient hematite nanoparticles modified biochar-clay granular composite for Cr(VI) removal and related mechanism. J. Clean. Prod. 2020, 276, 123009. [CrossRef]

3. Noori, A.; Donnelly, T.; Colbert, J.; Cai, W.; Newman, L.A.; White, J.C. Exposure of tomato (Lycopersicon esculentum) to silver nanoparticles and silver nitrate: Physiological and molecular response. Int. J. Phytoremed. 2019, 22, 40-51. [CrossRef] [PubMed]

4. Dimkpa, C.O.; Singh, U.; Bindraban, P.S.; Elmer, W.H.; Gardea-Torresdey, J.L.; White, J.C. Zinc oxide nanoparticles alleviate drought-induced alterations in sorghum performance, nutrient acquisition, and grain fortification. Sci. Total. Environ. 2019, 688, 926-934. [CrossRef] [PubMed]

5. Yusefi-Tanha, E.; Fallah, S.; Rostamnejadi, A.; Pokhrel, L.R. Zinc oxide nanoparticles (ZnONPs) as a novel nanofertilizer: Influence on seed yield and antioxidant defense system in soil grown soybean (Glycine max cv. Kowsar). Sci. Total. Environ. 2020, 738, 140240. [CrossRef]

6. Mehata, S.; Tamang, M.K.; Parajuli, K.R.; Rayamajhee, B.; Yadav, U.N.; Mehta, R.K.; Singh, D.R. Prevalence and Predictors of Zinc Deficiency among Children and Non-Pregnant Women in Nepal: Analysis of Nepal Micronutrients Status Survey 2016. Preprints 2020. [CrossRef]

7. Salehi, H.; De Diego, N.; Rad, A.C.; Benjamin, J.J.; Trevisan, M.; Lucini, L. Exogenous application of ZnO nanoparticles and ZnSO4 distinctly influence the metabolic response in Phaseolus vulgaris L. Sci. Total. Environ. 2021, 778, 146331. [CrossRef]

8. Phattarakul, N.; Rerkasem, B.; Li, L.J.; Wu, L.H.; Zou, C.Q.; Ram, H.; Sohu, V.S.; Kang, B.S.; Surek, H.; Kalayci, M.; et al. Biofortification of rice grain with zinc through zinc fertilization in different countries. Plant Soil 2012, 361, 131-141. [CrossRef]

9. Sharifan, H.; Moore, J.; Ma, X. Zinc oxide (ZnO) nanoparticles elevated iron and copper contents and mitigated the bioavailability of lead and cadmium in different leafy greens. Ecotoxicol. Environ. Saf. 2020, 191, 110177. [CrossRef]

10. Rossi, L.; Fedenia, L.N.; Sharifan, H.; Ma, X.; Lombardini, L. Effects of foliar application of zinc sulfate and zinc nanoparticles in coffee (Coffea arabica L.) plants. Plant Physiol. Biochem. 2019, 135, 160-166. [CrossRef]

11. Sun, W.; Dou, F.; Li, C.; Ma, X.; Ma, L.Q. Impacts of metallic nanoparticles and transformed products on soil health. Crit. Rev. Environ. Sci. Technol. 2021, 51, 973-1002. [CrossRef]

12. Man, Y.; Wang, B.; Wang, J.; Slaný, M.; Yan, H.; Li, P.; El-Naggar, A.; Shaheen, S.M.; Rinklebe, J.; Feng, X. Use of biochar to reduce mercury accumulation in Oryza sativa L: A trial for sustainable management of historically polluted farmlands. Environ. Int. 2021, 153, 106527. [CrossRef] 
13. Wang, Q.; Shaheen, S.M.; Jiang, Y.; Li, R.; Slaný, M.; Abdelrahman, H.; Kwon, E.; Bolan, N.; Rinklebe, J.; Zhang, Z. Fe/Mn- and $\mathrm{P}$-modified drinking water treatment residuals reduced $\mathrm{Cu}$ and $\mathrm{Pb}$ phytoavailability and uptake in a mining soil. J. Hazard. Mater. 2021, 403, 123628. [CrossRef] [PubMed]

14. Al-Salem, S.M.; Zeitoun, R.; Dutta, A.; Al-Nasser, A.; Al-Wadi, M.H.; Al-Dhafeeri, A.T.; Karam, H.J.; Asiri, F.; Biswas, A. Baseline soil characterisation of active landfill sites for future restoration and development in the state of Kuwait. Int. J. Environ. Sci. Technol. 2020, 17, 4407-4418. [CrossRef]

15. Pourang, N.; Noori, A. Heavy metals contamination in soil, surface water and groundwater of an agricultural area adjacent to Tehran oil refinery, Iran. Int. J. Environ. Res. 2014, 8, 871-886.

16. Sharifan, H.; Wang, X.; Guo, B.; Ma, X. Investigation on the Modification of Physicochemical Properties of Cerium Oxide Nanoparticles through Adsorption of Cd and As(III)/As(V). ACS Sustain. Chem. Eng. 2018, 6, 13454-13461. [CrossRef]

17. Mawia, A.M.; Hui, S.; Zhou, L.; Li, H.; Tabassum, J.; Lai, C.; Wang, J.; Shao, G.; Wei, X.; Tang, S.; et al. Inorganic arsenic toxicity and alleviation strategies in rice. J. Hazard. Mater. 2021, 408, 124751. [CrossRef]

18. Ma, X.; Sharifan, H.; Dou, F.; Sun, W. Simultaneous reduction of arsenic (As) and cadmium (Cd) accumulation in rice by zinc oxide nanoparticles. Chem. Eng. J. 2020, 384, 123802. [CrossRef]

19. Sharifan, H.; Ma, X.; Moore, J.M.; Habib, M.R.; Evans, C. Zinc Oxide Nanoparticles Alleviated the Bioavailability of Cadmium and Lead and Changed the Uptake of Iron in Hydroponically Grown Lettuce (Lactuca sativa L. var. Longifolia). ACS Sustain. Chem. Eng. 2019, 7, 16401-16409. [CrossRef]

20. Rossi, L.; Zhang, W.; Schwab, A.P.; Ma, X. Uptake, accumulation, and in planta distribution of coexisting cerium oxide nanoparticles and cadmium in Glycine max (L.) Merr. Environ. Sci. Technol. 2017, 51, 12815-12824. [CrossRef]

21. Taran, M.; Safaei, M.; Karimi, N.; Almasi, A. Benefits and application of nanotechnology in environmental science: An overview. Biointerface Res. Appl. Chem. 2021, 11, 7860-7870.

22. Wang, X.; Sun, W.; Zhang, S.; Sharifan, H.; Ma, X. Elucidating the effects of cerium oxide nanoparticles and zinc oxide nanoparticles on arsenic uptake and speciation in rice (Oryza sativa) in a hydroponic system. Environ. Sci. Technol. 2018, 52, 10040-10047. [CrossRef] [PubMed]

23. Yazdi, M.E.T.; Amiri, M.S.; Nourbakhsh, F.; Rahnama, M.; Forouzanfar, F.; Mousavi, S.H. Bio-indicators in cadmium toxicity: Role of HSP27 and HSP. Environ. Sci. Pollut. Res. 2021, 2021, 1-21. [CrossRef]

24. Avellan, A.; Yun, J.; Morais, B.P.; Clement, E.T.; Rodrigues, S.M.; Lowry, G.V. Critical Review: Role of Inorganic Nanoparticle Properties on Their Foliar Uptake and in Planta Translocation. Environ. Sci. Technol. 2021. [CrossRef] [PubMed]

25. Salehi, H.; Chehregani, A.; Lucini, L.; Majd, A.; Gholami, M. Morphological, proteomic and metabolomic insight into the effect of cerium dioxide nanoparticles to Phaseolus vulgaris L. under soil or foliar application. Sci. Total. Environ. 2018, 616-617, 1540-1551. [CrossRef]

26. Wu, J.; Wang, G.; Vijver, M.G.; Bosker, T.; Peijnenburg, W.J. Foliar versus root exposure of AgNPs to lettuce: Phytotoxicity, antioxidant responses and internal translocation. Environ. Pollut. 2020, 261, 114117. [CrossRef]

27. Hong, J.; Wang, C.; Wagner, D.C.; Gardea-Torresdey, J.L.; He, F.; Rico, C.M. Foliar application of nanoparticles: Mechanisms of absorption, transfer, and multiple impacts. Environ. Sci: Nano 2021, 8, 1196-1210.

28. Li, S.; Liu, J.; Wang, Y.; Gao, Y.; Zhang, Z.; Xu, J.; Xing, G. Comparative physiological and metabolomic analyses revealed that foliar spraying with zinc oxide and silica nanoparticles modulates metabolite profiles in cucumber (Cucumis sativus L.). Food Energy Secur. 2021, 10, e269. [CrossRef]

29. Zhang, T.; Sun, H.; Lv, Z.; Cui, L.; Mao, H.; Kopittke, P.M. Using Synchrotron-Based Approaches To Examine the Foliar Application of ZnSO4and ZnO Nanoparticles for Field-Grown Winter Wheat. J. Agric. Food Chem. 2018, 66, 2572-2579. [CrossRef]

30. Dou, F.; Soriano, J.; Tabien, R.; Chen, K. Soil Texture and Cultivar Effects on Rice (Oryza sativa, L.) Grain Yield, Yield Components and Water Productivity in Three Water Regimes. PLoS ONE 2016, 11, e0150549. [CrossRef] [PubMed]

31. Qiao, J.-T.; Liu, T.-X.; Wang, X.-Q.; Li, F.-B.; Lv, Y.-H.; Cui, J.-H.; Zeng, X.-D.; Yuan, Y.-Z.; Liu, C.-P. Simultaneous alleviation of cadmium and arsenic accumulation in rice by applying zero-valent iron and biochar to contaminated paddy soils. Chemosphere 2018, 195, 260-271. [CrossRef]

32. Ali, S.; Rizwan, M.; Noureen, S.; Anwar, S.; Ali, B.; Naveed, M.; Allah, E.F.A.; A Alqarawi, A.; Ahmad, P. Combined use of biochar and zinc oxide nanoparticle foliar spray improved the plant growth and decreased the cadmium accumulation in rice (Oryza sativa L.) plant. Environ. Sci. Pollut. Res. 2019, 26, 11288-11299. [CrossRef]

33. Zhang, W.; Ebbs, S.; Musante, C.; White, J.C.; Gao, C.; Ma, X. Uptake and Accumulation of Bulk and Nanosized Cerium Oxide Particles and Ionic Cerium by Radish (Raphanus sativus L.). J. Agric. Food Chem. 2015, 63, 382-390. [CrossRef]

34. Zhang, W.; Dan, Y.; Shi, H.; Ma, X. Elucidating the mechanisms for plant uptake and in-planta speciation of cerium in radish (Raphanus sativus L.) treated with cerium oxide nanoparticles. J. Environ. Chem. Eng. 2017, 5, 572-577. [CrossRef]

35. Martínez, J.M.; Galantini, J.A.; Duval, M.E.; López, F.M.; Iglesias, J.O. Estimating soil organic carbon in Mollisols and its particle-size fractions by loss-on-ignition in the semiarid and semihumid Argentinean Pampas. Geoderma Reg. 2018, 12, 49-55. [CrossRef]

36. Prescott, C.E.; Grayston, S.J.; Helmisaari, H.-S.; Kaštovská, E.; Körner, C.; Lambers, H.; Meier, I.C.; Millard, P.; Ostonen, I. Surplus Carbon Drives Allocation and Plant-Soil Interactions. Trends Ecol. Evol. 2020, 35, 1110-1118. [CrossRef] 
37. Bala, R.; Kalia, A.; Dhaliwal, S.S. Evaluation of Efficacy of ZnO Nanoparticles as Remedial Zinc Nanofertilizer for Rice. J. soil Sci. Plant Nutr. 2019, 19, 379-389. [CrossRef]

38. Chrysargyris, A.; Papakyriakou, E.; Petropoulos, S.A.; Tzortzakis, N. The combined and single effect of salinity and copper stress on growth and quality of Mentha spicata plants. J. Hazard. Mater. 2019, 368, 584-593. [CrossRef] [PubMed]

39. Jordan, G.J.; Carpenter, R.J.; Koutoulis, A.; Price, A.; Brodribb, T. Environmental adaptation in stomatal size independent of the effects of genome size. New Phytol. 2014, 205, 608-617. [CrossRef] [PubMed]

40. Ma, Y.; He, X.; Zhang, P.; Zhang, Z.; Ding, Y.; Zhang, J.; Wang, G.; Xie, C.; Luo, W.; Zhang, J.; et al. Xylem and Phloem Based Transport of $\mathrm{CeO}_{2}$ Nanoparticles in Hydroponic Cucumber Plants. Environ. Sci. Technol. 2017, 51, 5215-5221. [CrossRef] 